R. DAN BRUMBAUGH, JR.

Independent Economist

ANDREW S. CARRON

First Boston Corporation

\title{
Thrift Industry Crisis: Causes and Solutions
}

For THE SECOND TIME this decade, the thrift industry is in crisis. Once again thrift industry performance is deteriorating, failures are widespread, the regulators are besieged, and Congress has passed major banking legislation following protracted debate. Indeed, the current difficulties will be harder and more costly to resolve than those of the early 1980s. The implications-for competition in financial services, availability of funds for housing, and federal budget expenditures-are profound.

We begin our paper with a review of the thrifts' difficulties, from signs of trouble in the 1970s to the contemporary attempts to shore up the deposit insurance fund. In doing so, we show how regulatory forbearance during the early 1980s turned an initial crisis, caused by the thrift industry's undiversified portfolio of fixed-rate, long-term mortgages, into a near-disaster, in which hundreds of insolvent thrifts continue to operate. We assess the policy response to the current crisis and make recommendations of our own. Finally, we show how the recently deregulated thrift industry has been diversifying and moving away from its traditional role. We also discuss the outlook for the thrift industry in the context of regulatory reform, innovation, and competition.

We would like to thank the members of the Brookings Panel and James Barth for helpful comments on an earlier draft. 


\section{The Thrift Industry in Historical Perspective}

The thrift industry comprises primarily savings and loan associations and mutual savings banks; credit unions are sometimes included. Thrifts are generally distinguished from commercial banks in that they are regulated by different agencies; different deposit insurance corporations guarantee their deposits; and their balance sheets have historically included different assets and liabilities. ${ }^{1}$ Thrifts, which have had primarily long-term, fixed-rate assets, have relied principally on time and savings deposits for their funding. In contrast, commercial bank assets have included predominately shorter-term commercial loans, and their liabilities have been more diverse, including demand deposits and nondeposit sources of funds. This paper focuses on savings and loan associations and savings banks whose deposits are insured by the Federal Savings and Loan Insurance Corporation (FSLIC).

Table 1 shows the number and assets of savings and loan associations, mutual savings banks, and commercial banks. At the end of 1986, 55 percent of all U.S. financial intermediaries' assets were held by 3,987 savings institutions with approximately $\$ 1.4$ trillion in assets and 14,188 banks with approximately $\$ 2.8$ trillion in assets. ${ }^{2}$

Over the past twenty-five years, thrifts have grown more rapidly than banks. Despite a sharp drop in the number of savings institutions, thrifts maintained their share of U.S. financial intermediary assets at about 19 percent from 1960 to 1986, while commercial banking's share dropped from 43 percent to 37 percent. From 1960 to 1986, the number of thrifts fell approximately 40 percent, from 6,835 to 3,987 . Over the same period, the number of commercial banks grew 8 percent, from 13,126 to $14,188 .{ }^{3}$

The balance sheets of thrifts and banks have also changed. Mortgages, which made up 13 percent of bank financial assets in 1960, accounted for 19 percent of those assets in 1986. For savings and loan associations,

1. A summary of the regulatory structure of U.S. depository institutions will be found in Federal Home Loan Bank Board, Agenda for Reform (FHLBB, 1983), pp. 138-39.

2. U.S. League of Savings Institutions, 87 Savings Institutions Sourcebook (Chicago: U.S. League, 1987), pp. 46, $48,49$.

3. Ibid. 
Table 1. Number and Assets of Major Depository Institutions, Selected Years, 1970-86 Assets in billions of dollars

\begin{tabular}{|c|c|c|c|c|c|c|}
\hline \multirow{2}{*}{$\begin{array}{l}\text { End of } \\
\text { year }\end{array}$} & \multicolumn{2}{|c|}{$\begin{array}{l}\text { Savings and loan } \\
\text { associations }\end{array}$} & \multicolumn{2}{|c|}{$\begin{array}{l}\text { Mutual savings } \\
\text { banks }\end{array}$} & \multicolumn{2}{|c|}{ Commercial banks } \\
\hline & Number & Assets & Number & Assets & Number & Assets \\
\hline 1970 & 5,669 & 176 & 494 & 79 & 13,511 & 576 \\
\hline 1975 & 4,931 & 338 & 476 & 121 & 14,385 & 965 \\
\hline 1980 & 4,613 & 630 & 463 & 172 & 14,435 & 1,704 \\
\hline 1985 & 3,197 & 949 & 666 & 326 & 14,404 & 2,484 \\
\hline 1986 & 3,132 & 963 & 855 & 444 & 14,188 & 2,800 \\
\hline
\end{tabular}

Source: U.S. League of Savings Institutions, 87 Savings Institutions Sourcebook (Chicago: U.S. League, 1987), pp. $46,48-49,63$.

mortgages as a share of financial assets fell steadily from 73 percent in 1960 to 51 percent in 1986 . Time and savings deposits at banks have risen from 32 percent of financial assets in 1960 to 51 percent in 1986. The share of such accounts at thrifts declined from 88 percent in 1960 to 79 percent by $1986 .{ }^{4}$

Thus, thrifts have gained substantial increased control over financial assets in the United States, while the balance-sheet distinctions between thrifts and commercial banks have been eroding. Thrifts' importance to the U.S. economy has risen dramatically in another sense: the number of failed and insolvent thrifts insured by the Federal Savings and Loan Insurance Corporation jumped from 52 in 1980 to 551 in 1986, and the assets involved rose from $\$ 3$ billion to $\$ 140$ billion. ${ }^{5}$ As table 2 shows, the number of bank failures also rose substantially, from 10 in 1980 to 144 in 1986. Both the number of failures and the assets of the failed banks, however, are well below those for the thrift industry. What precipitated and continues to cause the thrift industry crisis, and the implications for regulatory reform, are the focus of the remainder of the paper.

4. Federal Reserve Board, Flow of Funds Accounts.

5. An institution fails when the appropriate regulator closes it and either sells the institution or liquidates its assets. Almost all closures are the result of insolvency, which for regulatory purposes occurs when the historical cost (or book value) of an institution's assets falls below the book value of the institution's liabilities. Since 1980, a growing number of thrift institutions have been allowed to remain open even though they were insolvent by the usual definition. 
Table 2. Number and Assets of Failed and Insolvent Thrifts and Banks, 1980-86

Assets in billions of dollars

\begin{tabular}{cccccc}
\hline & \multicolumn{2}{c}{$\begin{array}{c}\text { Failures and insolvencies } \\
\text { of FSLIC-insured thrift } \\
\text { institutions }\end{array}$} & & \multicolumn{2}{c}{$\begin{array}{c}\text { Failures of FDIC-insured } \\
\text { commercial banks }\end{array}$} \\
\cline { 2 - 3 } \cline { 5 - 6 } Year & Number & Assets & & Number & Assets \\
\hline 1980 & 52 & 3.0 & 10 & 0.2 \\
1981 & 146 & 32.4 & 10 & 4.9 \\
1982 & 453 & 95.5 & & 42 & 11.6 \\
1983 & 389 & 95.5 & & 48 & 7.2 \\
1984 & 475 & 112.1 & & 79 & 3.3 \\
1985 & 536 & 136.3 & 118 & n.a. \\
1986 & 551 & 140.0 & 144 & n.a. \\
\hline
\end{tabular}

Source: R. Dan Brumbaugh, Jr., Thrifts under Siege: Restoring Order to American Banking (Ballinger, forthcoming), table 3-2; Edwin J. Gray, Chairman, Federal Home Loan Bank Board (FHLBB), letter to Sen. William Proxmire (May 15, 1987), tables 2 and 15; and "200 Banks Facing Failure This Year," Washington Post, May 22, 1987.

n.a. Not available.

\section{The Plight of the Thrift Institutions, 1979-82}

The Federal Savings and Loan Insurance Corporation was created in 1934 to guarantee deposits in thrift institutions. In 1941, thirteen insured thrift institutions failed. Thereafter, until 1980, the number of failures reached ten only twice. This remarkable stability ended abruptly in 1980, when thirty-five thrifts failed. Of the total 890 failures of FSLIC-insured thrift institutions from 1934 through 1986, 75 percent occurred from 1980 through $1986 .{ }^{6}$

Warning signals in the 1970 s went largely unheeded. During the 1960 s, thrift industry net worth ranged from 6.5 percent to 7.0 percent of assets, but between 1970 and 1979, net worth rates dropped from 7.04 percent to 5.64 percent. $^{7}$ The decline reflected the effects of rising interest rates, which pushed up the cost of deposits faster than the thrifts could increase interest rates on mortgages. Thrifts faced substantial interest rate risk because fixed-rate mortgages, which made up nearly 80 percent of thrifts' assets in the 1970s, repriced at lengthier intervals than did deposits. In

6. Federal Home Loan Bank Board, unpublished data, as reported in James R. Barth, R. Dan Brumbaugh, Jr., Daniel Sauerhaft, and George H. K. Wang, "Insolvency and Risk-Taking in the Thrift Industry: Implications for the Future," Contemporary Policy Issues, vol. 3 (Fall 1985), table A-2, p. 24.

7. U.S. League, Sourcebook, pp. 56-57. 
addition, beginning in 1972, money market mutual funds began to provide higher-yielding accounts that were close substitutes for some thrift and bank accounts.

Regulatory constraints limited the ability of thrifts and banks to adapt. A form of price controls known as Regulation Q set interest rate ceilings on deposit accounts. Designed to reduce thrifts' interest rate risk by stabilizing the cost of funds, Regulation $Q$ triggered brief periods of disintermediation during the 1960 s and 1970s whenever market interest rates rose above the controlled rates. Interest rate restrictions began to be relaxed in 1978, when federal regulators authorized market-related interest rates on a money market certificate account with a six-month term and minimum deposit of $\$ 10,000$. Within a year, this account represented 20 percent of total thrift deposits. Assets were also constrained. Until the beginning of the 1980 s, variable-rate mortgages were limited to state-chartered thrifts in certain states.

With tight regulatory controls in incipient relaxation in 1979, thrift institutions were extremely vulnerable to interest rate increases when, in October, the Federal Reserve began to focus on money aggregates instead of interest rates as a tool to reduce inflation. ${ }^{8}$ Interest rates rose substantially. Savings and loan associations' average cost of funds,

8. One way to measure how rising interest rates increase liability costs for a thrift institution before the return on assets rises is to calculate interest rate "gaps." An interest rate gap is calculated by subtracting the dollar volume of liabilities repricing in one year, for example, from the dollar volume of assets repricing in the year. This number is then divided by the institution's total assets, giving the percent of liabilities in excess of assets that reprice in a year. The hedged gap accounts for the use of options and futures in reducing interest rate risk. Whenever repricing liabilities for a period exceed repricing assets the gap will be a negative number. The convention, however, is to drop the negative sign.

Data to calculate directly the thrift industry's interest rate gap were unavailable until March 1984. At that time, the industry's one-year, hedged interest rate gap was 40 percent. That means that 40 percent of all thrift liabilities repriced in one year after having netted out assets repricing in one year. Using income data, thrift cost of funds, and industry assets, one can indirectly estimate the industry interest rate gap near the beginning of the decade to have been approximately 72 percent.

Estimated indirectly, the interest rate gap equals the change in income due to changed interest rates divided by the change in interest rates times total assets. In 1981 the industry lost $\$ 7,114$ million (operating income) on $\$ 651,068$ million in assets when thrifts' cost of funds rose 150 basis points: $0.72=7,114 /(0.015)(651,068)$. Data on income from table 2-1; assets, table 2-2; and cost of funds, figure 2-1, in R. Dan Brumbaugh, Jr., Thrifts under Siege: Restoring Order to American Banking (Ballinger, forthcoming). 
which had been 7 percent in 1978, rose to more than 11 percent in $1982 .{ }^{9}$ During 1981 and 1982, the epicenter of the first thrift industry crisis of the $1980 \mathrm{~s}$, the cost of funds exceeded the average return on mortgages. ${ }^{10}$

In 1980, average rates paid by money market mutual funds were approximately 3 percentage points higher than the average rates paid by thrifts to depositors and other liability holders. By 1981, the differential was approximately 5 percentage points. Over six quarters in 1981-82, withdrawals at thrifts exceeded new deposits by more than $\$ 34$ billion. ${ }^{11}$ Crippling disintermediation was a possibility.

During the first three years of the 1980s, the industry was selling its best assets to bolster profitability and reported net worth. To counter net operating losses of $\$ 16$ billion during 1981-82, the thrifts sold appreciated assets that were valued on their balance sheets at original cost and recorded the gains as nonoperating income. Net nonoperating income rose from $\$ 496$ million in 1980 to $\$ 957$ million in 1981 and $\$ 3$ billion in 1982 . Further asset sales produced $\$ 2.5$ billion in nonoperating income in 1983. These tactics reduced total losses after taxes to $\$ 4.6$ billion in 1981 and $\$ 4.3$ billion in 1982 . The industry had positive net income of $\$ 2$ billion in 1983. ${ }^{12}$

The return to profitability was, for many firms, more apparent than real and reflected the incentives and effects not only of using book-value, as opposed to market-value, accounting, but also of using regulatory accounting principles (RAP). Although both RAP and the generally accepted accounting principles (GAAP) that apply to most public corporations rely primarily on historical rather than market values, RAP is generally more liberal in recognizing income and assets. ${ }^{13}$ The difference among the various net worth measures can be dramatic. In 1982, for

9. FHLBB, “ARM Index Rates" (August 14, 1987).

10. Andrew S. Carron, The Plight of the Thrift Institutions (Brookings, 1982), pp. 11-21.

11. Andrew S. Carron, The Rescue of the Thrift Industry (Brookings, 1983), p. 9.

12. U.S. League, Sourcebook, p. 50.

13. RAP net worth includes preferred stock; permanent, reserve, or guaranty stock; paid-in surplus; qualifying mutual capital certificates; income capital and net worth certificates; qualifying subordinated debentures; appraised equity capital; reserves; undivided profits (retained earnings); and net undistributed income. GAAP net worth excludes from this list qualifying mutual capital certificates; income capital and net worth certificates; qualifying subordinated debentures; and appraised equity capital. GAAP net worth includes deferred net gains (losses) on assets sold. 
example, industrywide RAP net worth was 3.69 percent of assets. GAAP net worth was 2.95 percent. Tangible net worth, which subtracts intangible assets from GAAP net worth, was 0.54 percent. Estimated market value net worth was -12.03 percent. ${ }^{14}$

These distinctions are important because the Federal Home Loan Bank Board uses the level of RAP net worth to judge whether a thrift is healthy and whether it should be more closely scrutinized. A thrift is categorized as a "supervisory case" when its RAP net worth falls below a specified percentage of liabilities, typically 3 percent. When a thrift becomes a supervisory case, the Bank Board can exercise broad control over it, but the Bank Board generally does not close a thrift until its RAP net worth is zero or negative. When difficulties arise, thrifts thus have a strong incentive to sell assets with positive market value to augment income and minimize the decline of RAP net worth. Worse, under current conditions, a closed institution will almost always have negative market value. ${ }^{15}$

\section{The Regulatory Response to the First Crisis}

The regulatory response to the problems of the early 1980 s proceeded along two lines: portfolio deregulation and relaxed safety and soundness controls. In retrospect, it is apparent that the relaxation of controls caused, or at least facilitated, the current crisis.

Congress passed the Depository Institutions Deregulation and Monetary Control Act in 1980. The act established a committee to phase out interest rate ceilings on deposits by March 1986. It also provided broader asset powers. Nationwide interest-bearing transaction accounts, the socalled NOW accounts, were introduced in 1980. In 1981, the Bank Board authorized federally chartered thrifts to make, purchase, and participate in adjustable-rate mortgages. To help thrifts attract new capital, the Board liberalized rules governing conversion from mutual to stock form in 1981. In 1982, Congress passed the Garn-St Germain Depository

14. Brumbaugh, Thrifts under Siege, table 2-7 and appendix table 2-1.

15. This closure rule has been described as a call option exercised by the Bank Board only when it is out of the money. See R. Dan Brumbaugh and Eric Hemel, "Federal Deposit Insurance as a Call Option: Implications for Depository Institution and Insurer Behavior,' Research Working Paper 116 (FHLBB, October 1984). 
Institutions Act, which further expanded thrift asset powers. In addition, at the state level, Florida expanded state-chartered thrift investment powers in 1980, as Maine had done in 1975, and Texas, in 1972.

These deregulatory reactions allowed thrifts to begin to adapt to changing market conditions. A second regulatory reaction took the form of forbearance: relaxed supervision and delayed closure of capitalimpaired thrifts. The minimum RAP net worth requirement was lowered from 5 percent to 4 percent in 1980 and to 3 percent in 1982. Fewer lownet-worth institutions thus became supervisory cases. In 1981, thrifts were permitted to defer losses on the sale of selected assets and to include qualifying mutual capital certificates (MCCs) and income capital certificates (ICCs) in RAP net worth. MCCs and ICCs were issued by the FSLIC in exchange for promissory notes from weakened thrifts. Similar net worth certificates (NWCs) were introduced in 1982. These provisions further cheapened the net worth requirement and reduced once again the number of RAP-insolvent thrifts or thrifts subject to supervisory control.

Although the deregulation of assets and liabilities helped cushion the effects of rising interest rates, deregulation alone would have been insufficient to avert an industrywide collapse. Altering the cost structure and portfolio mix of an industry requires years. What saved the industry was the unexpected and large decline in interest rates in 1982. Money market rates fell from their peak of over 16 percent to below 9 percent in $1983 .{ }^{16}$ After a slight increase in 1984, they continued their decline through 1986. Thrifts' costs of funds fell below the return on their assets in 1982 , for the first time in the 1980s, and the gap widened thereafter.

\section{Current Status of FSLIC-Insured Thrift Institutions}

Despite declining interest rates after 1984, the condition of many thrift institutions continued to deteriorate. The number of RAP-insolvent thrifts-those with RAP net worth of zero or less-rose steadily from 80 in 1982 to 251 in 1986; on a GAAP basis, the number of institutions with net worth of zero or less rose from 201 in 1982 to 468 in 1986 (table 3). In 1986, an additional 346 institutions had RAP net worth between zero and

16. Carron, The Rescue of the Thrift Industry, p. 3. 
Table 3. FSLIC-Insured Thrift Failures and Insolvencies and FSLIC Reserves, 1980-86 Assets and reserves in billions of dollars

\begin{tabular}{|c|c|c|c|c|c|c|c|}
\hline \multirow[b]{2}{*}{ Year } & \multicolumn{2}{|c|}{ Failed institutions } & \multicolumn{2}{|c|}{$\begin{array}{l}\text { GAAP insolvent } \\
\text { institutions }\end{array}$} & \multicolumn{2}{|c|}{ Weak institutions ${ }^{\mathrm{a}}$} & \multirow{2}{*}{$\begin{array}{l}\text { FSLIC } \\
\text { reserves }\end{array}$} \\
\hline & Number & $\overline{\text { Assets }}$ & Number & $\overline{\text { Assets }}$ & Number & Assets & \\
\hline 1980 & 35 & 2.9 & 17 & 0.1 & 280 & 35.1 & 6.5 \\
\hline 1981 & 81 & 15.1 & 65 & 17.3 & 653 & 126.7 & 6.2 \\
\hline 1982 & 252 & 46.8 & 201 & 48.7 & 842 & 204.3 & 6.3 \\
\hline 1983 & 102 & 16.6 & 287 & 78.9 & 883 & 242.7 & 6.4 \\
\hline 1984 & 41 & 5.8 & 434 & 107.3 & 856 & 350.4 & 6.0 \\
\hline 1985 & 70 & 6.5 & 466 & 129.8 & 673 & 270.1 & $7.5^{\mathrm{b}}$ \\
\hline 1986 & 83 & 13.8 & 468 & 126.2 & 515 & 255.1 & $3.6^{\mathrm{b}}$ \\
\hline
\end{tabular}

Source: FHLBB as reported in Brumbaugh, Thrifts under Siege, table 3-2. FSLIC reserves from U.S. League, Sourcebook, p. 63 .

a. GAAP net worth between zero and 3 percent of assets.

b. As of September 30 .

3 percent; 515 institutions had GAAP net worth between zero and 3 percent. In total, 18 percent ( $\$ 211$ billion) of thrift assets were in institutions at or below 3 percent RAP net worth; 33 percent $(\$ 381$ billion) of thrift assets were in institutions with GAAP net worth of 3 percent or less. ${ }^{17}$

Essentially, since 1982, the thrift industry has existed in two segments. One segment, the 983 FSLIC-insured thrifts with 1986 GAAP net worth of 3 percent or less, consists of insolvent and nearly insolvent thrifts whose performance has declined despite improving interest rates. Within this group, 341 institutions with $\$ 93$ billion in assets were GAAP insolvent and earning negative net income in 1986, up from 229 institutions the previous year. The second segment, the remaining 2,237 FSLIC-insured thrift institutions with assets of $\$ 784$ billion, largely produced the net income that has slightly bolstered the industry's aggregate net worth since 1982. (See table 4.)

The faltering segment of the industry benefited from the fall in interest rates but suffered from a coinciding deflation in real estate, primarily in the Southwest, particularly in Texas. The Southwest was also buffeted by falling oil prices. Difficulties in agriculture and timber also affected regional economic performance. In the affected areas, many thrifts that had sold assets to produce nonoperating income before 1982 were left

17. FHLBB, unpublished data, as reported in Brumbaugh, Thrifts under Siege, tables 2-5 and 2-6. 
Table 4. Earnings at FSLIC-Insured Thrift Institutions, 1985:1-87:2

Billions of dollars except where noted

\begin{tabular}{cccc}
\hline Period & $\begin{array}{c}\text { Net income of } \\
\text { profitable firms }\end{array}$ & $\begin{array}{c}\text { Losses of } \\
\text { unprofitable firms }\end{array}$ & $\begin{array}{c}\text { Share of firms } \\
\text { profitable } \\
\text { (percent) }\end{array}$ \\
\hline $1985: 1$ & 1.2 & 0.7 & 71 \\
$1985: 2$ & 2.0 & 0.9 & 83 \\
$1985: 3$ & 1.9 & 0.8 & 81 \\
$1985: 4$ & 2.3 & 1.2 & 79 \\
$1986: 1$ & 2.5 & 0.9 & 81 \\
$1986: 2$ & 2.3 & 2.1 & 79 \\
$1986: 3$ & 2.0 & 2.1 & 77 \\
$1986: 4$ & 2.3 & 3.2 & 74 \\
$1987: 1$ & 2.2 & 2.1 & n.a. \\
$1987: 2$ & 1.6 & 3.3 & n.a.
\end{tabular}

Source: FHLBB, "Fourth Quarter Earnings at FSLIC-Insured Thrift Institutions" (April 17, 1987); "U.S.-Insured S\&Ls' Losses Were \$1.6 Billion in Period," Wall Street Journal, September 28, 1987.

n.a. Not available.

with deteriorating assets after 1982. Even institutions that survived the early 1980s without asset sales were financially weakened by deflation and regional recession.

The continuing deterioration of the thrift industry has left regulators unable to cope with the problem. Ironically, one symptom of the FSLIC's helplessness is the reduction in the number of thrifts it closes each year. As table 3 shows, the number of closures dropped from a peak of 252 in 1982 to 102 in 1983 and even fewer in subsequent years-a drop that reflects the FSLIC's inability to pay the sums necessary to close an institution, not a decline in the number of insolvent thrifts. FSLIC reserves were stable at an average level of $\$ 6.4$ billion from 1980 through 1983. By 1985, the estimated cost to close all GAAP-insolvent thrift institutions was $\$ 15.8$ billion. ${ }^{18}$

Regulatory examination, supervision, and enforcement staffs have also been overwhelmed. The number of Bank Board examiners fell from 917 in 1982 to 891 in 1983 to 849 in $1984 .{ }^{19}$ Although the FSLIC staff grew from 34 in 1980 to 159 in 1985 , over half the staff had less than two years' experience. ${ }^{20}$

18. Edwin J. Gray, Chairman, Federal Home Loan Bank Board, letter to Sen. William Proxmire (May 15, 1987), table 13.

19. Brumbaugh, Thrifts under Siege, chap. 2, p. 22.

20. Barth, Brumbaugh, Sauerhaft, and Wang, "Insolvency and Risk-Taking," p. 3. 


\section{Causes of the Problem}

The cause of the current thrift problems is the moral hazard inherent in the deposit insurance system. Deposit insurance has been priced by statute at a flat percentage rate (essentially one-twelfth of one percent of total deposits) since its inception. The problem is that the insurance premium is set without regard to an institution's probability of failure, the risk of its portfolio, or the estimated cost to the insurer should it fail. The FSLIC and Federal Deposit Insurance Corporation have attempted to offset the moral hazard primarily with capital requirements, regulation, examination, supervision, and enforcement.

Capital requirements are intended to induce risk-averse behavior (as do deductibles in casualty insurance) and to act as buffer against capital erosion due to unexpected adverse economic difficulties. Regulation is put in place to discourage specific conduct perceived by the regulator to be excessively risky. Examination and supervision are designed to monitor compliance with regulations. Enforcement is supposed to deter noncompliance through the threat of legal action.

For thrifts, this entire mechanism had foundered by 1982. Even though the FSLIC closed a record number of insolvent institutions in 1982, it left a record 201 open, giving the owners and managements incentive to take risks. Gains from risk, after all, accrue to owners and managers while losses accrue to the insurer. But the incentive to take greater risk does not exist only at insolvency but at other levels of decreasing net worth. As an institution nears the level of net worth at which it will become a supervisory case, it may be tempted to take increased risks to avoid supervisory control. As it approaches insolvency, it may try to avoid that by taking greater risks. In 1982, 1,824 FSLIC-insured institutions with 60 percent of industry assets $(\$ 504$ billion) were failing the RAP net worth requirement that had applied in $1980 .{ }^{21}$ Thus, a majority of the thrifts had reached net worth levels low enough to create incentives for greater risk taking.

If more thrifts had been shareholder-owned, deposit insurance had

21. FHLBB, unpublished data, as reported in Brumbaugh, Thrifts under Siege, table 2-6. 
not existed, and information had been freely available, the market would have imposed discipline. Stock prices would have adjusted to reflect the market values of assets and liabilities, and general creditors would have taken control of insolvent institutions. Management would thus have had less incentive to take risks and to use book-value accounting methods to inflate accounting income.

In 1980, stock thrifts (both public and private) composed only 20 percent of the thrift industry and held 27 percent of industry assets. With 96 percent of industry liabilities in insured deposits, insured creditors had no direct incentive to monitor thrifts' conduct and performance. ${ }^{22}$ And since uninsured creditors had been paid the full value of their liabilities by the FSLIC when it closed an institution, even they had little direct incentive to monitor thrifts. Most important, the FSLIC, the general creditor with the most to lose in thrift insolvencies, made decisions based on RAP. There were abundant incentives for institutions to maximize RAP net worth.

The extent to which deregulation may be contributing to the current problem depends upon the effects of the interaction of deregulation with increasing insolvency and is difficult to determine. Deregulation provided insolvent institutions with additional asset and liability pricing structures with which to take greater risks. Several studies have evaluated econometrically the effect of such new asset categories as direct investments (equity investments and direct investment in real estate) on both the probability of failure for an institution and the cost to the FSLIC once an institution fails. ${ }^{23}$ No study has found an association between the probability of failure and direct investments. Some, but not all, of the studies have found a positive association between FSLIC costs and direct investment in the portfolios of closed thrifts. In the most recent such study, the average time elapsed between GAAP insolvency for the

22. Ibid., tables $1-5$ and 2-10.

23. James R. Barth, R. Dan Brumbaugh, Jr., and Daniel Sauerhaft, "Failure Costs of Government-Regulated Financial Firms: The Case of the Thrift Institutions," Research Working Paper 123 (FHLBB, October 1986); James R. Barth, R. Dan Brumbaugh, Jr., Daniel Sauerhaft, and George H. K. Wang, "Thrift Institution Failures: Causes and Policy Issues," Proceedings of a Conference on Bank Structure and Competition (Federal Reserve Bank of Chicago, 1985), pp. 184-216; George J. Benston, "An Analysis of the Causes of Savings and Loan Association Failures," Monograph Series in Finance and Economics, 1985-4/5 (Salomon Brothers Center for the Study of Financial Institutions, New York University, 1985). 
institutions and closure was eleven months. The implication is that the incentives caused by insolvency, rather than inherent risks of direct investments, may have been the problem.

Finally, failure to close insolvent thrifts created incentives to take excessive risks across the asset and liability frontier. Reducing minimum net worth requirements also allowed low net worth institutions, which would have otherwise been subject to supervisory status, to take greater risks, and abetted adverse selection by increasing leverage opportunities.

\section{Regulatory Response to the Changing Thrift Industry Crisis}

From the beginning of the thrift crisis until March 1985, the regulatory response to the growing number of insolvent thrifts focused on interest rate risk. In 1983, thrifts were allowed to extend the maturities of their liabilities by borrowing from the Federal Home Loan Banks for up to twenty, instead of ten, years. A 1984 rule required thrift boards of directors to establish an interest rate risk policy. Throughout the period, the Bank Board encouraged the use of adjustable-rate mortgages.

When the problems of credit risk began to eclipse the difficulties associated with interest rate risk, the regulatory response focused on asset and liability restrictions. In 1984, the Bank Board proposed a regulation (later declared illegal by a federal court and never implemented) to limit the use of broker-originated deposits by high-risk-taking insolvent thrifts paying rates above industry averages. The intent was to confine the taking of risks to thrifts with the ability, not merely the willingness, to take them.

The first three regulations dealing with greater risk taking by FSLICinsured thrifts were adopted by the Bank Board in March 1985. One regulation generally limited direct investments to 10 percent of assets or twice net worth, whichever was greater. The board also required additional net worth for thrifts growing more than 15 percent a year. In addition, the Bank Board began phasing out techniques that had permitted certain thrifts to maintain minimum net worth requirements below the 3 percent level applying to the industry as a whole.

In 1986 and again in June 1987 the Bank Board extended and tightened the direct-investment regulation. The final regulation was applicable to certain land loans and nonresidential construction loans as well as direct 
investments. In 1986, the Bank Board also required a gradual increase in minimum net worth from 3 percent to 6 percent RAP net worth.

Finally, in August 1987, President Reagan signed into law the Financial Institutions Competitive Equality Act of 1987. Included in the law is an "FSLIC Recapitalization" provision, developed by the Treasury Department and the Bank Board, that authorizes the Federal Home Loan Bank System to establish a financing corporation to borrow funds on behalf of the FSLIC to close insolvent thrifts. To pay back the principal, a portion of the bank system's capital will be used to purchase zerocoupon bonds pledged to principal repayment. The interest on the borrowings is scheduled to be paid from regular and supplemental deposit insurance premiums paid by insured thrifts. To prevent thrifts from changing insurance corporations in order to escape paying the supplemental premium, another provision established a one-year moratorium on thrifts seeking to switch from FSLIC to FDIC coverage. ${ }^{24}$ The act also lowered to 0.5 percent the minimum net worth requirement for thrifts whose financial difficulties have been caused by deteriorating regional economic conditions rather than by imprudent management.

\section{Solving the Problem: Who Will Pay? How Much?}

There is little dispute that current closure policy actually encourages insolvent thrifts to take great risks to survive. Nor is there much argument that the Bank Board's risk-control mechanism is overwhelmed and inadequate to control risk taking by insolvent thrifts. Valid questions, however, do exist about the size of the problem, how much money is required to cure it, how quickly the money should be raised and spent, and whose money should be used-the thrifts', commercial banks', or taxpayers'.

\section{MAGNITUDE OF THE PROBLEM}

At a minimum, the 341 FSLIC-insured thrift institutions with negative GAAP net worth and earning negative net income at year-end 1986 represent a baseline from which to measure the extent of the problem.

24. Joint Explanatory Statement of the Committee of Conference, Congressional Record (July 31, 1987), pp. H6899-6902. 
These institutions had $\$ 93$ billion in assets, a negative GAAP net worth of $\$ 10.1$ billion, and a negative net income of $\$ 3$ billion..$^{25}$

From 1980 through 1983, the FSLIC's average actual resolution cost as a percentage of assets of closed thrifts was 7.2 percent. In 1984, it rose to 14.7 percent and was 14.5 percent in $1985 .{ }^{26}$ The cost increase in part reflected the deteriorating asset quality of closed institutions. Most closings early in the period were due to interest rates, and the effect of rising interest rates was relatively easy to calculate. Calculation of the value of institutions with asset-quality problems is more difficult and uncertain, leading to higher FSLIC costs.

In 1986, the FSLIC estimated that it cost, on average, 23.5 percent of the total assets of a closed institution to resolve a FSLIC case. ${ }^{27}$ Multiplying this closure cost ratio by the assets of unprofitable GAAPinsolvent thrifts in 1986 suggests that the cost to close these thrifts will be $\$ 21.9$ billion. The $\$ 11.8$ billion dollar difference between the GAAP net worth of these institutions and the estimated cost of resolution suggests the difference between GAAP and market-value net worth. Because generally accepted accounting principles can inflate profitability and other performance indexes, and because weakened thrift institutions have incentives to do so, it is not unreasonable to use all GAAP-insolvent thrifts in 1986 to expand the baseline estimate of the size of the problem. At year-end 1986, there were 468 GAAP-insolvent institutions with $\$ 126$ billion in assets. Based on the 1986 FSLIC estimate of the cost of resolving a case, the cost to close them all would be $\$ 29.6$ billion.

At the same time that thrift insolvencies were increasing in the weak segment of the industry, new capital was pouring into healthy institutions. Many institutions with mutual charters (depositor-owned) converted to the stock form of organization. In 1980 stock thrifts held 27 percent of industry assets; by 1986 that share had risen to 62 percent. ${ }^{28}$ This trend is further evidence of the split of the thrift industry into haves and have-nots. It is also an indication that a charter to run a thrift institution is valued by the market, despite the well-known difficulties of the industry.

With the liberalization of thrift operating powers, many financial

25. FHLBB, unpublished data, as reported in Brumbaugh, Thrifts under Siege, table 3-1.

26. Ibid., table 2-9.

27. Ibid.

28. Ibid., table 1-5. 
activities can be undertaken as easily by a thrift as by a commercial bank. Because thrifts have lower capital requirements and, in many instances, more liberal operating authority than commercial banks, a thrift charter has become a bargain compared with a bank charter. With a relatively modest investment, a new thrift owner can gain access to insured deposits, substantial leverage, limited downside risk, and the potential for large gains. In financial terms, purchase of a thrift is tantamount to buying an inexpensive option on interest rate futures, real estate values, or some other asset within the purview of a thrift charter.

RECAPITALIZATION OF THE FSLIC

The intention of the 1987 Financial Institutions Competitive Equality Act was to enable the FSLIC to pay the cost of liquidating the insolvent thrifts from the proceeds of bonds issued by its newly created Financing Corporation (FICO). The FICO is to be capitalized by an infusion of up to $\$ 3$ billion from the Federal Home Loan Banks. A total of $\$ 10.8$ billion in bonds may be issued by the FICO, with not more than $\$ 3.75$ billion issued each year. The FICO's capital will be used to pay back the principal on the bonds through the purchase of zero-coupon government and corporate bonds. Semiannual interest will be paid out of the regular and supplemental thrift industry deposit insurance premiums.

The first $\$ 500$ million in FICO bonds, issued in September 1987, yielded 10.73 percent to maturity, approximately 90 basis points above comparable-maturity U.S. Treasury bonds. At a yield of 10.73 percent and a price of par, the present value of the principal paid at maturity is only 4.35 percent of the face amount of a thirty-year bond and 35.16 percent for a ten-year bond; coupon interest payments account for the remainder. ${ }^{29}$ Thus the value of the bonds is largely dependent on the availability of deposit insurance premiums to make interest payments.

It is possible that future FICO issues will have lower yields, which would reduce future claims on deposit insurance premiums. If the rate dropped to, say, 10.00 percent, annual interest on $\$ 10.8$ billion would be $\$ 1.08$ billion. Total annual deposit insurance premiums for 1987 , based on average deposits in insured institutions during the first six months of

29. Authors' calculations based on semiannual compounding at the quoted yield, and data from Wall Street Journal, October 1, 1987, p. 57. 
the year, are estimated at $\$ 1.86$ billion. ${ }^{30}$ The estimated debt-service coverage would be 1.7 , which would be ample. But even if interest rates decline as assumed, two critical assumptions remain: first, that there will be no claims on deposit insurance premiums, other than for debt service, over the next thirty years; and second, that the level of deposits will not decline over the next thirty years. Both assumptions are open to question.

That there will be no new claims on the insurance premiums is unlikely. Our estimates of the total cost to close insolvent institutions substantially exceed the $\$ 10.8$ billion available through recapitalization. The recent volatility in the thrift industry's performance and in the economic conditions affecting the industry indicate that the cost could escalate substantially. It seems reasonable to conclude that an annual expenditure of $\$ 3.75$ billion for two years and $\$ 3.3$ billion in a third year may barely keep up with the rate of growth of the cost of closing insolvent thrifts. It is also likely that new problems will develop and require expenditures by the FSLIC.

Nor will the deposit base of the thrift industry necessarily grow as it has in the past. From 1982 to 1985 , deposits at FSLIC-insured thrifts grew at an average annual rate of 15.0 percent. In 1986, the deposit growth rate was 5.5 percent. During the first half of 1987, deposits rose at an annual rate of only 1.6 percent. ${ }^{31}$ Higher capital requirements on incremental assets, increased competition, and the potential transfer of thrifts from FSLIC to FDIC coverage could further slow or even reverse the growth trend.

Table 5 shows the results of an exercise to determine the sensitivity of FICO debt coverage to these two assumptions. (Debt coverage is defined here as the present value of projected insurance premiums divided by the present value of projected interest payments, both discounted at 10 percent annually.) The left-hand column shows alternative deposit growth rates for the industry; the remaining column headings show alternative levels of additions to the FSLIC caseload, expressed as a percentage of industry deposits. A $\$ 1$ billion a year increase in the cost of resolving the problems of insolvent thrifts would

30. Authors' calculations based on FHLBB, "Thrift Institution Activity in June" (August 11, 1987), table 1.

31. Ibid., and U.S. League, Sourcebook (various issues). 
Table 5. Debt Coverage Ratio for the FSLIC Financing Corporation under Alternative Economic Assumptions ${ }^{a}$

\begin{tabular}{|c|c|c|c|c|c|}
\hline \multirow{2}{*}{$\begin{array}{l}\text { Annual deposit } \\
\text { growth rate } \\
\text { (percent) }\end{array}$} & \multicolumn{5}{|c|}{ Annual increase in problem cases as percent of deposits } \\
\hline & 0.00 & 0.05 & 0.10 & 0.15 & 0.20 \\
\hline-10 & 0.82 & 0.62 & 0.43 & 0.23 & 0.03 \\
\hline-5 & 1.14 & 0.87 & 0.59 & 0.32 & 0.05 \\
\hline 0 & 1.72 & 1.31 & 0.89 & 0.48 & 0.07 \\
\hline 5 & 2.88 & 2.18 & 1.50 & 0.81 & 0.12 \\
\hline 10 & 5.47 & 4.16 & 2.84 & 1.53 & 0.22 \\
\hline 15 & 11.72 & 8.90 & 6.09 & 3.28 & 0.47 \\
\hline
\end{tabular}

Source: Authors' calculations based on FHLBB, "Thrift Institution Activity in June" (August 11, 1987).

a. This analysis is not adjusted for the more than $\$ 800$ million in prepaid premiums that have already been spent, but which will be credited against future cash premium requirements. Debt coverage ratios would be reduced by approximately 0.05 if these credits were taken into account. Debt coverage is defined as the present value of projected insurance premiums divided by the present value of projected insurance payments, both discounted at 10 percent annually.

represent approximately 0.11 percent of current deposits. The table shows that the ability of deposit insurance premiums alone to meet the debt service on FICO bonds is highly sensitive to these two assumptions.

This exercise is relevant to potential holders of FICO debt, but that is not its primary purpose. After all, it is highly unlikely that a federally chartered agency would be permitted to default on its debt (although impaired liquidity is a possibility). Should premium collections fall short, it is likely that Congress would step in to make additional resources available, either to pay bondholders directly or to defray competing FSLIC expenses to make the necessary funds available. The important implication of the exercise is that a premium shortfall is likely and that when it happens it will trigger another major initiative in resolving the ongoing thrift problem. What is difficult to determine is the timing.

\section{ALLOCATING THE COSTS}

Whether the surviving thrift institutions can bear the cost of closing insolvent thrifts is one question. Whether they should is another. To address that issue, it is helpful to recall the two major purposes of deposit insurance. The first was to avoid the large social costs of runs, to prevent the insolvency of some institutions from leading to runs on solvent institutions and disrupting the intermediation process and payments mechanism. The second was to protect depositors who were unable to 
assess the safety of depository institutions. In both cases, the purpose was to provide certain protections for society. Nor was the insurance premium established by Congress large: it has generated FSLIC reserves exceeding 2 percent of insured deposits only twice since 1934. It does not seem to have been the intent of Congress that deposit-insurance premiums should cover extraordinary expenses.

General tax revenues thus appear to be a legitimate source of funds for closing insured thrifts and commercial banks in emergencies. Because, in this particular case, the industry lobbied for, and won, regulatory forbearance, with costs escalating as a result, it may be appropriate for the thrifts to bear some of the burden beyond regular insurance premiums. But even that is debatable because until at least 1983, and more likely 1984, the consequences of forbearance were only dimly perceived by anyone.

Another frequently mentioned source of funds for the FSLIC is a merger with the FDIC. The object of such a merger is to find funds to close thrifts without having to use general revenues. But there is less justification for commercial banks to pay for failing thrifts than there is for surviving thrifts to pay. To the extent that growing competition between banks and thrifts led to thrift failures, having commercial banks pay for the failure is like having the victor pay the creditors of the vanquished. Unless there were a mechanism to ensure that the FDIC fund would be sufficient to close all insolvent banks, moreover, it would be inappropriate to merge the funds and use the FDIC to cure part of the FSLIC's deficiency, especially when the commercial bank failure rate is also high. Nevertheless, the increasing similarity of bank and thrift powers and regulations will likely lead eventually to the consolidation of bank and thrift regulatory agencies, regardless of the outcome of the current thrift crisis.

\section{Regulations Developed since 1983}

Regulations developed since 1983 can be divided into four major categories: portfolio regulation (allowable assets and liabilities), interestrate-risk regulation, capital requirements, and accounting and appraisal standards. The major issue before the Bank Board has been how to control risk taking of weak and insolvent thrifts awaiting closure. Part 
of the issue is how to curb the risk-taking incentives of weakened thrifts without unnecessarily restricting healthy institutions. The distinction between weak and healthy is essentially the distinction between poorly and well-capitalized thrifts.

Portfolio regulation has been addressed primarily through the directinvestment regulations of 1985, 1986, and 1987, which limit direct investments and selected loans to a fixed percentage of total assets or a multiple of net worth, whichever is higher. Portfolio regulation has also been affected by the 1987 requirement that capital be higher for higher percentages of those assets targeted by the direct-investment regulation. These approaches are designed to curtail risk taking by poorly capitalized thrifts while allowing healthy thrifts to diversify.

Critics of portfolio regulation point out that portfolio risk is a function of the variances and covariances of all assets and liabilities in a firm's portfolio. The direct-investment regulation and the direct-investment component of the capital requirement focus solely on the perceived variances of the targeted assets. Furthermore, a poorly capitalized thrift with a revealed preference for high risk taking may be presumed to react to specific asset limitations by shifting, much as a firm will attempt to shift the incidence of a tax, to other nonproscribed assets to achieve the same level of risk. Direct-investment limitations will thus tend to be ineffectual in curtailing risk taking. In addition, because they apply to well-capitalized thrifts, they may limit the ability of those thrifts to diversify their portfolios and thereby reduce risks.

Although econometric evaluations have found a positive association betwen FSLIC costs and direct investments, they provide little justification for the current approaches. In addition, because the fundamental culprit is insolvency, the direct-investment regulations may give regulators a false sense of security and slow their search for funds to close insolvent thrifts and to build an adequate damage-control apparatus.

The second form of regulation is that aimed to lower interest rate risk. The Depository Institutions Deregulation and Monetary Control Act of 1980 and the Garn-St Germain Act of 1982 both provided for asset and liability diversification to allow thrifts to close their interest rate gap. Authorization of adjustable-rate mortgages created an opportunity to diversify portfolios without moving away from mortgages. The expansion of asset powers by state regulators for state-chartered thrifts also provided diversification opportunities. 
The Bank Board's direct-investment regulations, however, created a schism between the Bank Board and state regulators. One consequence was a chilling effect on diversification because even well-capitalized thrifts were aware that several nonmortgage asset categories triggered alarm among examiners. The Bank Board was compounding this effect by publicly praising the traditional role of thrifts in housing finance.

The interest rate risk of the industry measured by interest rate gaps fell dramatically but remained substantial. Between March 1984 and March 1986 the one-year hedged gap fell from 40 percent to 21 percent. ${ }^{32}$ Given assets of approximately $\$ 1$ trillion, this means that a 100-basispoint increase in interest rates-a parallel upward shift of the yield curve-would reduce thrift income approximately $\$ 2$ billion. Thus, the industry is still vulnerable to interest rate increases.

By setting the ultimate capital requirement, the third form of regulation, at 6 percent, the Bank Board was implicitly stating that 6 percent is the capital buffer needed to protect the FSLIC and that institutions below that level ought to be considered supervisory cases. The formula adopted by the Bank Board in 1986 to build net worth gradually does so by requiring a fraction of average industry net income to be retained.

Another approach would have been to raise the net worth requirement immediately. That would have enabled the Bank Board to take tight control of imprudent institutions with net worth between 3 percent and 6 percent and would have been a step toward a better damage-control mechanism. It would also have created a substantial incentive for thrifts to use their ingenuity to raise capital. The Bank Board's move to raise capital requirements was undercut by the provision in the 1987 FSLIC recapitalization legislation allowing thrifts whose difficulties are caused by regional economic slowdowns to maintain only 0.5 percent net worth. Any institution with a book-value net worth that low is almost certainly market-value insolvent. Given the incentive to take risk when insolvent, this provision is particularly dangerous.

The final type of Bank Board regulation provided for the classification of assets as substandard, doubtful, and loss, and required reserves at specified levels for each category. In addition, the Bank Board toughened standards for appraisals to be used under some circumstances by thrifts.

32. FHLBB, unpublished data, as reported in Brumbaugh, Thrifts under Siege, table $3-5$. 
The industry reaction has been that application of the classification of assets regulation has been harsh and arbitrary and that the appraisal requirements are onerous.

\section{Policy Prescription}

A sum substantially exceeding $\$ 10.8$ billion will be required to close all insolvent thrifts. The funds ought to and will probably come largely from general revenues. Less clear is what the optimum flow of funding should be. There is a limit to how quickly the FSLIC can assess institutions and arrange for their closure at minimum cost. Efficient spending requires the development of an effective triage mechanism to take control of insolvent institutions and to restrain their risk taking until they can be closed. The mechanism that exists today is understaffed, underfunded, and inadequate. The Bank Board, the FSLIC, and Congress should focus attention and funding on making the triage mechanism work.

The triage program has three basic parts: information gathering, damage control, and disposal. The current debate has focused almost solely on disposal, on finding the money to allow the FSLIC to effect mergers and liquidation of insoivent thrifts. The other two components, however, are equally important.

\section{INFORMATION GATHERING}

Information gathering relies primarily on the Bank Board's examination and supervisory staffs and on financial reporting. Even though the staff of examiners has almost doubled, from 856 in 1985 to 1519 in 1986, it continues to be overwhelmed. Examiners must monitor three groups of institutions: the insolvent, the weak, and the remainder. Based on GAAP, the first group numbered 468 in 1986. The weak included almost certainly the 515 with GAAP net worth of 3 percent or less, but greater than double that if the cutoff is 5 percent net worth. There is probably less than one examiner for each insolvent and weak thrift. An emergency expansion of the staff of examiners and their supervisors is overdue.

Financial reporting takes the form, primarily, of quarterly financial 
reports compiled and evaluated by the Office of Policy and Economic Research (OPER) in the Bank Board. In the past two years, the OPER staff has atrophied. More important, though related, the reports themselves have not changed to reflect changes in the industry. Two modifications are necessary. First, data on relevant lines of business should be refined. Second, wherever feasible, market values should be reported. Substantial resources should be made available to do that and to rebuild the OPER staff.

Reliable information will make damage control possible. It can establish the order of battle by delineating the insolvent, the weak, and the strong, and, within that order, the major malefactors in risk taking. It then can be used to allocate examiners and to determine appropriate supervisory actions.

\section{DAMAGE CONTROL}

Effective damage control will require increased takeovers of weak and insolvent thrifts. In April 1985, the Management Consignment Program (MCP) was created to take control of the worst insolvent thrifts that could not be closed because of inadequate FSLIC reserves. Though the procedures are complicated, the MCP basically removes control of an institution from its management and owners, establishes a new board of directors, and selects new management (generally, executives from stronger thrifts). There were twenty-nine MCP institutions in 1986, up from twenty-five in 1985. Critics of the MCP charge that institutions remain too long in the program and continue to deteriorate and to pay above-industry averages for deposits, just as their predecessors did. The MCP, however, has little alternative, given the lack of funds to close the thrifts and to provide liquidity if deposit rates fell and caused withdrawals. Another criticism has been that the FSLIC has not developed management contracts that establish the proper incentives. ${ }^{33}$

Notwithstanding these criticisms, the MCP or some successor will be needed to control the risk taking of hundreds of thrifts until disposal can be arranged. The MCP can also provide valuable information for examiners, supervisors, and policymakers about the conduct and performance

33. Lawrence J. White, "Facing the Issues," Outlook of the Federal Home Loan Bank System (May-June 1987), p. 24. 
of insolvent thrifts. It can provide, as well, first-hand portfolio data to those who ultimately dispose of the institutions in the program. The MCP should be expanded.

Damage control also involves enforcement. The enforcement division of the Bank Board was recently expanded and made an independent division, formally separate from the office of General Counsel. The primary role of the division is to identify fraudulent behavior and take appropriate legal action, thus providing a deterrent to such conduct by others. This division, too, should be expanded.

Information gathering and damage control are not addressed by the FSLIC recapitalization legislation. They are, however, as important as the recapitalization itself.

\section{DISPOSAL}

Disposal is primarily the domain of the FSLIC. When the Bank Board examination staff considers an institution hopelessly insolvent, it traditionally notifies the FSLIC and arranges for the institution's transfer to the FSLIC caseload. The FSLIC then evaluates the thrift and arranges for its disposal, primarily through a merger or liquidation. In 1986 there were 27 FSLIC-assisted mergers or other types of assistance cases and 23 liquidations. With at least 341 to 468 additional insolvent thrifts, the caseload must increase and will require more staff.

An important, inadequate, and generally neglected division of the FSLIC is the Analysis and Evaluation Division (AED). Although it is responsible for evaluating the portfolios of FSLIC cases and providing data for the FSLIC staff that negotiates with would-be acquirers, its methods are simplistic and antiquated and may have led to severe information asymmetries in the bidding process in past mergers. The division should be thoroughly overhauled and transferred to OPER, where more sophisticated staff and direction are available to evaluate the balance sheets of FSLIC cases.

The key to our approach is to use information and damage control to establish an optimal flow of funds for disposal and to reduce overall disposal costs. To date, information and damage control have been neglected. It may be wise to divert a nonnegligible part of the FSLIC recapitalization to the information and damage-control functions; if not, other funds should be found. 


\section{Outlook}

As the thrift industry has moved away from its traditional role as a housing lender, the capital market has developed alternative means of channeling funds to homebuyers. The role of thrifts and banks is converging, and it is becoming increasingly difficult to justify separate regulatory and deposit-insurance systems for the two.

\section{THRIFT INSTITUTION BALANCE SHEETS IN THE EIGHTIES}

Until 1980, the balance sheets and income statements of thrift institutions were relatively simple. Assets were primarily single-family mortgage loans (some held as mortgage-backed securities) and shortterm U.S. government securities (held as a source of liquidity). Liabilities were mostly savings deposits and borrowings from the Federal Home Loan Banks. Earnings were primarily a function of the interest margin between assets and liabilities.

This structure was largely the result of legislation and regulation. When the rules were relaxed in the early 1980s, thrifts used the opportunity to diversify. The assets of the industry have more than doubled since the beginning of the decade, and most of the growth has come from activities not permitted before regulatory reform. Because thrift assets have traditionally been long-lived, the incremental sources of growth are a better indication of activity than are the balance sheet aggregates.

Table 6 presents a view of the thrift industry categorized by activity. For each activity, two measures are presented, one based on assets and one based on income. The distinction is necessary because for activities such as leasing, the investment precedes the income, while for activities such as mortgage banking, the value of the earning "asset" does not appear on the balance sheet. Although the categories and the measures of activity are somewhat arbitrary, they are representative of broad trends under way in the industry.

The table shows that traditional thrift activities have slowed substantially since 1980; they are the only activity to have shown a clear decline. Thrifts are holding fewer mortgage loans in their portfolios, and an increasing share of those are in the form of mortgage-backed securities. The role of thrifts as portfolio lenders is declining. 
Table 6. Indicators of Thrift Industry Diversification, 1980 and 1986

Percent

\begin{tabular}{lrr}
\hline & \multicolumn{2}{c}{ End of year } \\
\cline { 3 - 3 } Activity & 1980 & 1986 \\
\hline Traditional thrift & & \\
$\quad$ Mortgage assets share & 70.6 & 54.0 \\
$\quad$ Mortgage income share & 79.5 & 67.8 \\
Mortgage banking & & \\
$\quad$ Net loans serviced/held & 3.2 & 18.7 \\
$\quad$ Mortgage fee income share & 4.8 & 9.6 \\
Trading & & \\
$\quad$ Investment assets share & 0.5 & 4.2 \\
$\quad$ Investment income share & 9.9 & 11.1 \\
Real estate development & & \\
$\quad$ Real estate assets share & 13.6 & 22.6 \\
$\quad$ Real estate income share & 0.5 & 0.5 \\
Banking & & \\
$\quad$ Nonmortgage loan assets share & 1.4 & 5.6 \\
$\quad$ Nonmortgage income share & 3.6 & 7.3 \\
\hline
\end{tabular}

Source: Authors' calculations as described in the text based on FHLBB, unpublished data.

Mortgage banking activity has increased. Fee income from origination and servicing has become an important source of revenues. Another measure of mortgage banking, the value of loans serviced for others, net of loans serviced by others, has increased nearly 500 percent as a share of total loans held.

Some thrifts have shifted their asset mix away from mortgage loans toward investment securities, earning income from the spread between asset yield and the cost of liabilities and recording gains when appreciated investments can be sold at a profit. Both measures have shown increases since 1980 .

The share of assets devoted to real estate development has increased 66 percent since 1980 . Gross revenues from real estate activity are not reported separately, nor are revenues from service corporations engaged in real estate development identified. Only net income is shown in the table, and that has not risen because of substantial losses by thrifts in many areas of the country.

Thrifts are also beginning to offer a full range of nonmortgage loans, paralleling the services provided by commercial banks. The share of nonmortgage loan assets has increased 300 percent, while the revenue share from those sources has doubled. 
INFORMATION, MORTGAGE-BACKED SECURITIES, AND THRIFT REGULATION

Financial intermediaries exist essentially because of imperfect information between borrowers and lenders. If borrowers and lenders knew who each other were and could assess each others' financial capabilities and needs, no need would exist for financial intermediaries. Information among borrowers and lenders is improving. One reflection of that is the expanding market for securities backed by the assets traditionally held in portfolio by thrifts and banks. Mortgage-backed securities were the first asset-backed security and are the most developed.

In 1986, 58 percent ( $\$ 257$ billion) of all one- to four-family mortgages originated in the United States were sold in the secondary market and became part of mortgage-backed securities. Only 17 percent of such mortgages were sold in the secondary market in 1980. By 1986, 34 percent ( $\$ 518$ billion) of the total one- to four-family mortgage stock was securitized, up from 12 percent in $1980 .^{34}$

Through the purchase of mortgage-backed securities, the capital market is supplanting thrifts as the chief holder of mortgages-the traditional role that differentiated thrifts from other intermediaries and created their vulnerability to rising interest rates. Early in this transition, some analysts worried that if thrifts ceased to hold mortgages, the supply of housing finance would decline. But from 1979 to 1986 the total dollar volume of residential mortgages nearly doubled while thrifts' share of holdings dropped from 51 percent to 34 percent. If mortgage-backed securities are allocated to the holders, the thrifts' shares are higher, but show a comparable decline. ${ }^{35}$

The market for mortgage-backed securities has proved remarkably adaptable. One of the drawbacks of the original mortgage-backed securities was that unexpected principal repayments led to uncertain cash flows in the securities. In 1983, a new security called a Collateralized Mortgage Obligation (CMO) was introduced to alleviate cash-flow uncertainty. Generally, a CMO will separate a mortgage pool into several security classes or tranches and direct interest and principal payments

34. Brumbaugh, Thrifts under Siege, table 7-2 and chap. 7, p. 8.

35. U.S. League, Sourcebook, pp. 29-31. 
to fast-pay and slow-pay tranches. From mid-1983 through the first half of $1987, \$ 116$ billion in CMOs had been issued. ${ }^{36}$

\section{CONCLUSIONS}

The diversification of thrift activities and the development of mortgage-backed securities have eliminated much of the justification for a government-facilitated specialized housing finance lender called a thrift. The regulatory implication is that government-influenced balance-sheet differences between thrifts and banks should be eliminated. Without balance-sheet differences, the justification for separate regulatory and deposit-insurance agencies is also eliminated. As thrift balance sheets become more like bank balance sheets, regulation of thrifts should be folded into the bank regulatory apparatus. Now is the time to begin.

Although thrifts have so far been affected more than commercial banks have by the rapidly improving information between borrowers and lenders, banks will ultimately be equally hard hit. Asset-backed securities have expanded from single-family fixed-rate mortgages to multifamily mortgages, adjustable-rate mortgages, commercial mortgages, car and light truck loans, and credit card receivables. Commercial paper, once issued by only the largest corporations, is now being issued by smaller companies. It is becoming difficult to imagine financialintermediary assets that will be immune to the increasingly improving information between borrowers and lenders. As asset-backed securities erode intermediary assets, revenue from those assets will fall. The shortrun effect will be to intensify incentives for cost reduction. Ultimately, however, the revenue reduction will force intermediaries to diversify further, posing increasingly difficult problems for regulators.

As that scenario unfolds, it will be useful to recall the lessons of the thrift industry crisis. Resisting the deregulation of balance sheets in the face of changing economic and technological conditions is futile and costly. When institutions deteriorate because of changing economic forces, forbearance is also costly. Lowering net worth requirements and relaxing accounting standards, for example, undermine monitoring and control, giving rise to incentives to take greater risks and facilitating the risk taking. Instead, net worth requirements should be maintained at levels that reduce moral hazard and provide the deposit insurance agency

36. First Boston Corporation, CMO Quarterly (September 1987), p. 1. 
a substantial buffer against unexpected adverse events. When institutions fall below the requirement, intense examiner and supervisory scrutiny is essential. The increasing pressure on balance sheets suggests the need to reform accounting and reporting requirements, especially the development of market values. Whenever possible, a financial intermediary should report the marked-to-market value of its assets and liabilities.

Strict net worth requirements and accounting standards are essential for developing an adequate closure rule, without which regulators are likely to repeat the worst error made in the thrift industry crisis: waiting to close institutions until their market value was already negative. Closing an institution before its market value is exhausted avoids substantial rescue costs. If we are correct about the threat to thrifts and banks of improving information, Congress should address these issues with a sense of urgency.

\section{EPILOGUE}

Although we have taken for granted the continuation of deposit insurance, it is worth questioning whether it continues to be appropriate. It may be that the government can assure greater future stability with less of a contingent liability for itself by requiring substantial minimum net worth for formerly insured institutions, by demanding improved financial reporting and accounting, and by closing-probably through the Federal Reserve Board-institutions with positive but diminishing net worth. ${ }^{37}$

In contemplating such an apparently dramatic change, it may be well to observe that financial stability today is less a function of the deposit insurance agency funds than of the perceived willingness and ability of Congress to place the full faith and credit of the U.S. government behind guaranteed deposits. Credible protection against loss is what is important to depositors, not whether it is accomplished through an insurance fund or stricter regulation. Closure of insolvent institutions with public confidence in the remaining open, solvent institutions would protect against the prospect of destabilizing runs.

37. This approach was previously described in John H. Kareken and Neil Wallace, "Deposit Insurance and Bank Regulation: A Partial Equilibrium Exposition," Journal of Business, vol. 51 (July 1978), pp. 413-38. 


\section{Comments and Discussion}

Dwight M. Jaffee: Andrew Carron and Dan Brumbaugh have prepared an excellent paper, using good judgment regarding what to omit as well as what to include. The result is an accurate, concise, and stimulating account of the current thrift crisis.

Overall, I agree with most of their main conclusions, although I would have stated several of them more strongly. This difference is illustrated in the following three points, for each of which I briefly summarize the authors' position and then give my own stronger version.

First, the authors argue that the procedures used by FSLIC during the crisis had serious flaws, especially its closure rules-the rules FSLIC uses to determine when to close sick thrifts-which allowed sick institutions to operate much too long. Instead, they say, FSLIC should have enforced stricter net worth standards, and it should be doing so now as well. I would say that FSLIC's performance during the crisis was a disaster.

Second, the authors indicate that the unique function and structure of thrift institutions is disappearing. I would say that there is no longer any distinctive role for thrift institutions.

Third, the authors note that the purpose of deposit insurance is changing. I would say that the deposit insurance system urgently needs a major overhaul.

As a result of these differences, the authors and I come down on different sides of one major issue, whether or not it would have beenor still is-a good idea to merge FSLIC into FDIC. We all agree that the new FSLIC restructuring plan provides but a slender safety margin for FSLIC and the thrifts to service the interest on the debt to be issued as part of the plan. However, I feel that merging FSLIC into FDIC is a far better solution to the crisis than is restructuring FSLIC, whereas the 
authors are not as positive about a merger of the two deposit insurance funds.

My case for merging FSLIC into FDIC depends on the three points listed above, so I will now briefly expand on each.

FSLIC has been badly managed since the beginning of the crisis, as is reflected in the high price we must now pay to bail it out. The problem is that, by law, the board members of the Federal Home Loan Bank Board system are also the directors of FSLIC. A fundamental conflict of interest is built into the system. FHLBB board members should, and certainly do, give priority to the survival of thrift institutions; FSLIC board members should give priority to the survival of FSLIC. The conflict is particularly evident during a crisis that threatens the survival of both FSLIC and the thrifts.

From the beginning, this overlapping structure has been reflected in FSLIC's strategy for dealing with the crisis. This strategy was to delay closing institutions as long as possible, hoping that falling interest rates would solve the problems. Ironically, even though the interest rate gamble worked, with interest rates falling much more than most people would have expected, the remaining problems are worse than anyone expected. FSLIC is just unwilling to grapple with the, admittedly, hard and dirty business of closing sick institutions. Carron and Brumbaugh are right in relating the escalating problems to the "moral hazard" of sick institutions, but there is also a moral hazard in having a regulator with two hats.

In arguing that thrift institutions no longer have a distinctive role, Carron and Brumbaugh point out that deregulation now allows thrifts to behave more like commercial banks; that innovations such as "securitization" give the thrifts a means for doing so; and that the transformation of thrifts is really happening.

I think it is important to add that the historical basis for the special role of thrifts, the priority accorded low-cost mortgage financing for single-family housing in the United States, has all but disappeared. Two things have really happened. First, Congress, and certainly the present administration, is no longer pushing housing as a social priority. Second, mortgage banking is now an attractive and highly competitive business. Thrifts are still big players in this business, but so are General Motors and General Electric. In fact, thrifts are now trying to limit the activities of the Federal National Mortgage Association (FNMA) and the Federal 
Home Loan Mortgage Corporation (FHLMC) so that these agencies will not be of as much help to competing mortgage bankers.

While I think it is right to argue that thrifts and commercial banks will soon be indistinguishable, we should not lose sight of the fact that both of these institutions also compete with money market funds. Although the respective market shares seem to have stabilized for the moment, ultimately I expect all banking institutions will look more like money market funds. A key point is that our banking institutions are very expensive to operate: they need a spread of 2 percentage points or more to break even. Given a choice, I think consumers will go for lower-cost models.

In discussing the FSLIC restructuring plan, Carron and Brumbaugh seem to be saying that everyone realizes that taxpayer money will be needed eventually to bail out FSLIC. We may all know this, but this view is certainly not being reflected in policy. As a good example, current policy gives the impression that deposit insurance is "mutual" insurance-the surviving institutions will pay for the failing ones. This is reflected, for instance, in the supplementary premiums that thrifts now have to pay for FSLIC insurance and in the use of FHLBB net wortharguably owned by the thrifts-to provide the equity for the FSLIC restructuring.

There are strategic reasons for portraying FSLIC insurance as mutual insurance. It suggests that FSLIC and the thrift industry can solve their own problems, helping them make the case that they should remain independent. It also keeps the costs of restructuring FSLIC out of the government budget.

However, treating the deposit insurance fund as a mutual plan is likely to create serious problems. For one thing, bank runs become more likely because people will recognize that mutual insurance will not work if every bank is suspect. A similar outcome was observed recently in the states of Ohio and Maryland, where inadequate insurance funds actually created bank runs. For another thing, it is easy to imagine a vicious circle in which the sick thrifts bring down the sound thrifts with them and sink the whole industry. As a result, sound thrifts have an obvious incentive to pull out of FSLIC and in fact are already looking for bank merger partners or negotiating "exit fees," cash settlements with FSLIC, in order to withdraw.

Underlying all of this is that FSLIC, as well as FDIC, is no longer 
insuring institutions primarily against bank runs. Instead, FSLIC is now insuring institutions primarily against losses created by credit risk, interest rate risk, and fraud. There is a big difference between providing insurance against bank runs, which I do not think is too hard and may not even be necessary, and providing insurance against credit and interest rate risk, which cannot work in the manner of current federal deposit insurance. So sometime soon we will have to overhaul the deposit insurance system.

The possibilities for reform are numerous, but let me just raise an extreme alternative. Most mutual funds-both money market and bond and stock funds-operate without any deposit insurance and have done just fine. In particular, runs on mutual funds do not occur because investors recognize (or think) that they can always sell or redeem their shares, albeit at prices that properly reflect the value of the assets owned by the fund. As a result, investors want to know what they are buying, fund charters are specific about the allowable assets, and cautious investors buy funds with safe assets.

My conclusion is that the FSLIC crisis would be better resolved by merging FSLIC into FDIC than by restructuring FSLIC according to the current plan. I see several advantages. First, the current FSLIC plan is an open invitation for FSLIC managers to continue to operate just as they have for the past five years, resolving cases in the best interests of thrifts more than in the best interests of FSLIC. This approach is fine if FSLIC really is a mutual insurance fund, but we know that it is not. Second, if there is no special role for thrifts, then there is no need for the additional expense of running two parallel networks of insurance funds and regulatory apparatus. And, third, it will be easier to overhaul one deposit insurance fund than to overhaul two of them, especially given that one of them is bankrupt.

William Poole: Andrew Carron and Dan Brumbaugh provide a thorough examination of an important and difficult policy problem. A large part of the thrift industry is bankrupt, FSLIC is bankrupt, and the federal policy to deal with the mess is in disarray. The authors discuss the current state of the industry, how it got into such a mess, and what the federal government should do about it. I will summarize the key features of their analysis and add my own comments as I do so.

To discuss the current state of the industry it is necessary to start with 
some accounting issues. Three different accounting systems are used to measure the balance sheet of a thrift. The first involves regulatory accounting principles (RAP). The second system is known as generally accepted accounting principles (GAAP). The authors discuss some of the differences between these two sets of accounting principles. A third system, marking assets and liabilities to their market values, provides the most accurate picture of a firm's condition whenever it is possible to obtain reasonably good estimates of the market values. Market-value accounting is universally used by investment companies such as mutual funds; these firms strike a new balance sheet at the end of every day based on the closing prices of the assets in their portfolios. The main problem with market-value accounting is that it may be quite difficult to measure the value of certain assets for which no organized market trading exists.

The thrifts, and many other regulated financial firms, use accounting principles determined by their regulators. These principles evolved many years ago based on the view that these firms, most of which are highly leveraged, should not be required to show transitory changes in asset values. The assumption was that a temporary fall in asset values would wipe out reported net worth and lead to runs by depositors. This accounting principle would be satisfactory if it were really true that changes in asset values display a high degree of negative serial correlation. However, finance research over the past twenty-five years has built an overpowering case that changes in asset values are best considered permanent at the time they occur.

Regulatory accounting principles, then, are based on a fundamentally flawed economic theory of how asset values behave. RAP is responsible, I believe, for much of the problem we see today in the thrift industry. Employing RAP has permitted firms, regulators, and Congress to believe that problems were much smaller than they actually were and to believe that losses might well be reversed. These accounting principles have also permitted thrifts to pursue portfolio policies that would be discouraged if they were routinely exposed under market-value accounting.

RAP not only misstates balance sheet positions but also permits wide latitude for manipulating income statements. A thrift can report earnings-RAP earnings—by selling assets that happen to show capital gains while continuing to hold assets that show capital losses. Thus, the thrift can report substantial earnings in a period in which substantial losses 
were in fact sustained. This freedom to manipulate both the balance sheet and the income statement means that regulatory accounting principles are really creative regulatory accounting principles, or CRAP.

The thrifts' earnings data reported by Carron and Brumbaugh in table 4 and in the text are misleading. It would be useful if their paper included tables reporting estimates of income on a true economic basis-that is, income reflecting unrealized capital gains and losses. It would also be useful to have a table reporting annual balance sheet data from 1965 to date on a market-value basis. These data would provide a far more accurate picture of the state of the industry than we have at present.

Some 35 percent of the thrift institutions existing in 1980 no longer exist, having disappeared through mergers and liquidations. Moreover, of the 3,000 thrifts in existence at the end of 1986, about 350 are surely insolvent and another 600 are probably insolvent. That is, about onethird of the thrifts whose doors are now open would in fact be closed down tomorrow if we were to insist that a thrift maintain positive net worth at the current market values of assets and liabilities. The magnitude of the disaster that has hit this industry is astonishing. Of course, if interest rates continue to rise as they have so far this year, even more thrifts will go under.

Early in their paper Carron and Brumbaugh say that "relaxed safety and soundness controls . . caused, or at least facilitated, the current crisis." At the end of the paper they say that deposit insurance itself may be the villain. This conclusion arises from the fact that deposit insurance provides a perverse incentive for a thrift's management to increase risk when the thrift is already insolvent or nearly so.

In my view, the problem is much deeper than the authors suggest, and the policy errors occurred much longer ago. Throughout the postwar period the thrift industry has relied heavily on the political power of the housing lobby. From the end of World War II until 1965 the industry operated in a favorable economic and political environment. Long-term interest rates were almost always higher than short-term rates, and the industry prospered by borrowing short and lending long. Interest rates rose gradually over this period, but the increase in long rates never occurred rapidly enough to cause a serious deterioration in the value of home mortgages in the thrifts' portfolios.

The thrifts benefited from a number of federal policies. They enjoyed favorable tax treatment. Regulation Q interest ceilings applied to com- 
mercial banks but not to thrifts. Government policy encouraged a steady supply of high-quality mortgages. Urban expressway construction encouraged home building in the suburbs, and many of the mortgages on these new houses were insured by the FHA. Cranky fiscal conservatives were about the only ones worried that an institution issuing long-term mortgages financed by demand money was inherently unsound.

When interest rates rose sharply in the credit crunch of 1966 the federal government rode quickly to the rescue. Regulation Q ceilings were extended to the thrifts to prevent the more aggressive ones from bidding money away from other members of the industry. The ceiling applied to the thrifts was set a little higher than the ceiling applying to commercial banks so that the thrifts would have a competitive advantage in attracting funds. Throughout the 1970s Regulation Q was administered in a conscious effort to protect the health of the thrift industry.

Of course, other elements of public policy prevented the industry from saving itself. There were legal impediments or outright prohibitions on issuance of variable-rate mortgages. Some of these restrictions were at the federal level and some at the state level. For example, Vermont once raised its usury ceiling on mortgages while providing that the higher ceiling would not apply to variable-rate mortgages. Actions of this type were taken in the name of consumer protection. Also, as the authors point out, the industry could not diversify its portfolio because portfolio restrictions held it to investing almost exclusively in home mortgages.

In the 1970s the thrift industry and its supporters underestimated the force of competition. Especially in the late 1970s money market mutual funds grew rapidly, and no amount of tinkering with Regulation Q ceilings could hold off the onslaught of that competition. The consequences of mismatched asset and liability maturity structures came home to roost. By 1981 interest rates had gone so high and the pressure had been on for so long that the crisis broke into the open. By this time many thrifts had exhausted their ways of reporting satisfactory earnings and satisfactory capital. The federal government came to the rescue again with relaxed capital requirements and funny money called income capital certificates and net worth certificates. The blatant tax subsidy called the All Savers Certificate provided a low-interest source of funds to the thrifts because the interest was tax free to those buying the certificates.

Even though interest rates declined sharply after mid-1982, the government rescue remains incomplete. Indeed, some of the steps taken in the early 80 s have made the situation worse. As the authors emphasize, 
by permitting nearly insolvent institutions to remain open, the regulators have encouraged additional excessive risk taking on the part of thrifts trying desperately to save themselves.

So, where are we today? The first shoe has dropped. A large part of the industry has closed and FSLIC is bankrupt. The second shoe is soon to hit the ground. Somebody is going to lose money, and a lot of it.

Before asking who should pay we must be clear about who can be made to pay. The government's present approach involves advances of funds from the Treasury with the expectation that the funds will be repaid through deposit insurance premiums on the surviving thrifts. That solution may simply not be feasible. Carron and Brumbaugh argue that the amounts involved are so large that they may well cause deposit insurance premiums to be too high to be sustainable. After all, firms in the thrift industry have the option to restructure themselves as commercial banks. Or, if that avenue of escape is cut off through changes in the chartering rules, the return in the business may be too low to attract depositors and investors.

The authors argue that the funds to bail out the insolvent firms in order to pay off insured deposits "ought to and probably will come largely from general revenues." I would have no quarrel with this judgment if the case of the thrifts stood alone. However, because it almost surely does not, we need to be concerned about the general issue of bailouts. After all, the Pension Benefit Guaranty Corporation is in trouble; there are suggestions that the federal government should help to bail out the ailing steel industry; many large banks are in trouble from LDC, energy, and agricultural loans. And I am sure that around this table we can come up with a dozen more potential bailout situations.

The issue here is one of political economy. Can we fashion a solution to the thrifts' problem that reduces the incentive for other industries to behave in ways that may eventually require bailouts? My own judgment is that the federal government should drive a very hard bargain to minimize the bailout precedent. The bargain should load as much of the cost as possible on the thrift industry. In fact, the government should assess more than it is likely to collect.

Driving a hard bargain may be the only way to obtain two essential long-run reforms in the structure of the thrift industry and its regulation. First, the industry needs a larger base of uninsured capital. This capital could consist of equity, uninsured capital notes, or uninsured deposits. Second, regulators should insist on market-value accounting. Capital 
requirements mean little unless assets and liabilities are marked to market.

The thrift industry as we knew it from 1945 to 1980 is dead. Capital accumulated during the favorable years before 1965 was exhausted by the interest rate increases in the 1970s and early 1980s. There may well be a place for firms specializing in housing finance, but the decision on the matter should be made by the market within the context of public policies that maintain a "level playing field." In any event, all financial firms must maintain a reasonable maturity match on the asset and liability sides of the balance sheet, or use various financial instruments such as futures and options to hedge a mismatch. Given the politics of the present situation, I see no orderly way for government policy to force thrifts to structure their balance sheets properly. To reach the desirable end, the government will have to pressure the industry to accept major reforms. The government in the end will have to pay, but it should agree to pay only if the industry accepts those reforms.

If the industry will not accept reforms, then government attempts to collect may well force most traditional thrifts to recharter as commercial banks or to go out of business. Such an outcome would solve the problem. That solution, however unsatisfactory, would be better than a continuing governmental obligation to pay for the inevitable losses that will occur from time to time in firms with highly mismatched asset and liability maturity structures.

\section{General Discussion}

James Duesenberry agreed with the authors that the performance of the U.S. thrift industry as a whole has been dismal, but said it should not be forgotten that some institutions, and indeed some entire regions, have performed well. Massachusetts thrift institutions provide one such example. In Massachusetts, thrifts benefited from the early introduction of variable-rate mortgages and from diversification by consumer and security lending activities that were not allowed in other regions. Furthermore, participation in a mutual insurance fund provided a reason for Massachusetts thrifts to accept greater supervision and monitoring of fellow members. According to Duesenberry, the experience of the Massachusetts thrifts indicates that the problems experienced by insolvent or near-insolvent institutions are not intrinsic to the industry. 
Duesenberry also emphasized the political origin of some of the industry's problems. Unlike the FDIC, which is under the control of an independent board of directors, FSLIC is a creature of Congress, which must approve funds for examinations and other enforcement mechanisms. In his opinion, this dependence creates a conflict of interest. The real estate industry has substantial political clout and its own special interests in the thrift industry. This helps explain both Congress's reluctance to authorize funds for FSLIC enforcement of industry standards and its lack of enthusiasm for regulatory reform, when these seem at variance with the housing industry's self-interest. John Kareken agreed with the thrust of Duesenberry's remarks, noting that the position of the Federal Home Loan Bank Board was compromised by its dual role as advocate and regulator of the industry. Hence he believes that the housing industry and Congress bear some responsibility for the current crisis.

A number of participants discussed the future of the thrift industry. Robert Hall argued that the industry is an anachronism and that raising deposit insurance premiums would only accelerate its demise and replacement by more efficient institutions. He suggested that the deposittaking and lending activities of the thrifts could be readily replaced by mutual funds and the mortgage-backed securities market. He observed that according to Dwight Jaffee's data, mutual funds are more efficient than thrifts, requiring a smaller interest-rate spread to operate profitably. In addition, he noted, mutual funds would not require deposit insurance against runs, since they do not issue a face-value liability. Hall also observed that the mortgage origination function of thrifts was being replaced by mortgage brokers and the secondary market. Anthony Downs, on the other hand, was concerned about the prospect of a rapid demise of thrift institutions, expressing skepticism about the capacity of the secondary market and mutual funds to absorb the $\$ 800$ billion in mortgages currently held by the thrifts.

Duesenberry disagreed with the view that the specialized role of the thrift industry was now obsolete. He argued that the traditional thrift role of evaluating credit risk continues to be important and that an institutional arrangement in which such judgments are backed with capital avoids moral hazard. In his assessment, the move towards mortgage-backed securities and securitization in other forms of credit will result in a deterioration in the quality of these instruments since the originators of the loans do not retain responsibility for them. Carron 
disagreed, arguing that third-party guarantors had an incentive to ensure that quality standards are maintained. He also believes that in the "senior/subordinated" financial structures currently in use, the originator of the loan retains a sufficient interest to avoid this problem. William Brainard agreed with Duesenberry about the continuing role for thrifts, emphasizing the historical role of the thrifts in converting illiquid assets into a liability of certain capital value. He noted that although mutual funds could grow to hold the mortgages now held by thrifts, their "deposit" liabilities, unlike thrifts', would not be of fixed capital value. The elimination of thrifts would be contractionary unless the government or Federal Reserve were to engage in extremely large market transactions, buying longer-term securities and issuing short securities to serve as an enlarged base for money market funds.

In Alan Blinder's view, a better understanding of forces in the historical development of the thrift industry is a prerequisite to assessing the importance of its future role. In the United States and in other countries, the function of lending in customer markets and the function of providing liabilities that serve as money, or near money, have traditionally been combined in the same enterprises. Blinder observed that although there are examples of businesses that serve only one role, the dominant form combines the two functions. In his view, until it is clear whether this regularity has been the result of market forces or of the regulatory environment, and until it is clear what the appropriate role of regulation itself should be when the private creation of near monies is involved, it will not be possible to say whether the demise of thrifts is desirable. 